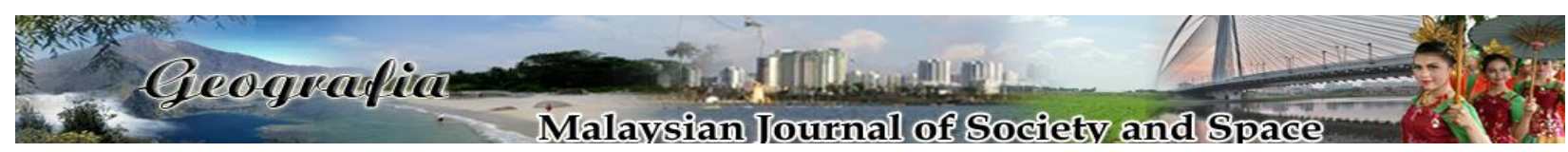

\title{
Pemetaan isoglos varian dialek Terengganu berasaskan aplikasi sistem maklumat geografi
}

\author{
Shahidi A.H., Mohamad Firdaus Azaharuddin, Rahim Aman \& Muhamad Syahmi Shabri \\ Pusat Kajian Bahasa, Kesusasteraan dan Kebudayaan Melayu, Fakulti Sains Sosial \& Kemanusiaan, \\ Universiti Kebangsaan Malaysia.
}

Corresponding author: Shahidi A.H (email: zedic@ukm.edu.my)

Received: 13 August 2020; Accepted: 25 October 2020; Published: 29 November 2020

\begin{abstract}
Abstrak
Makalah ini bertujuan menyerlahkan peta variasi Dialek Terengganu yang wujud di Lembangan Sungai Terengganu dengan mengaplikasikan perisian Sistem Maklumat Geografi (Geographical Information System). Variasi leksikal 'aku', 'kamu' dan 'mereka' yang berfungsi sebagai subjek dalam ujaran yang dituturkan oleh masyarakat kampung yang tinggal di sepanjang Lembangan Sungai Terengganu dimanfaatkan sepenuhnya dalam memenuhi objektif kajian ini. Kajian ini menerapkan kaedah kajian lapangan yang melibatkan teknik temu bual informan dan rakaman. Aspek geolinguistik dan bukan linguistik telah dikemukakan dalam makalah ini bagi mengukuhkan kewujudan isoglos bagi lapan varian dialek kawasan yang merangkumi varian Makam Lama, varian Tajin, varian Butut, varian Pauh, varian Bidur, varian Kuala Pueh, varian Jenagor dan varian Baung. Taburan varian untuk kebanyakan kawasan kajian di sepanjang LST adalah berbeza mengikut pengaruh pertuturan penuturnya dengan keadaan geografi kawasan kajian. Ringkasnya, penyebaran sesuatu dialek adalah sangat dipengaruhi oleh keadaan geografi atau bentuk muka bumi di persekitaran kawasan kajian seperti lembangan sungai, bukit bukau, hutan, bertanah pamah dan tasik. Dapatan kajian juga membuktikan tiada sebarang penemuan dialek luar atau bahasa Orang Asli di sepanjang Lembangan Sungai Terengganu. Kajian ini memberi implikasi kepada penambahan kosa ilmu linguistik khususnya bidang kajian Geografi Dialek, di samping mempertingkatkan kefahaman tentang variasi dialek Melayu dalam pendidikan variasi bahasa/dialek Melayu di sekolah, universiti dan kementerian pendidikan. Kajian ini adalah signifikan kepada para ahli linguistik Melayu yang berusaha meneruskan legasi pengkajian dialek di Malaysia dan kelestarian budaya Melayu.
\end{abstract}

Katakunci: dialek Melayu, geografi dialek, lembangan sungai Terengganu, peta isoglos, sistem maklumat geografi 


\title{
Isogloss mapping of Terengganu dialect variations based on geographic information system applications
}

\begin{abstract}
This paper aims to illustrate the map of the Terengganu Dialect variations that exist on the basin of the Terengganu River by applying the software of Geographical Information System. Variations of lexical 'aku' (I), 'kamu' (you) and 'mereka' (them) which functions as the subject in the utterance spoken by the village communities living along the River Basin, Terengganu is fully utilized in accomplishing the objectives of this study. This study applies the method of field survey which involves the technique of interview and recording. Aspects of geolinguistic and non-linguistic have been presented in this paper for strengthening the existence of isogloss for eight variants which include Makam Lama, Tajin, Butut, Pauh, Bidur, Kuala Pueh, Jenagor, and Baung. The distribution of variant for most study areas along the LST varies according to the influence of the speaker's speech with the geographical conditions of the study area. In other words, the spread of a dialect is strongly influenced by the geographical conditions or landforms in the environment of the study area such as river basins, hills, forests, lowlands and lakes. The findings of the study also prove the absence of any external dialects or Indigenous People dialect along the River Basin, Terengganu. This study gives implications to the addition of the linguistic studies particularly the Geographical Dialect study, as well as to enhancing the understanding of the variations of the Malay dialects in the education of language variation/dialect of Malay in schools, universities and the ministry of education. This study is significant to the members of the Malay linguistics of trying to continue the legacy of scholarship dialect in Malaysia and the sustainability of the Malay culture.
\end{abstract}

Keywords: Malay dialect, geographical dialect, Terengganu river basin, isogloss map, geographical information system

\section{Pengenalan}

Penyebaran sesuatu dialek adalah sangat dipengaruhi oleh keadaan geografi atau bentuk muka bumi di persekitaran kawasan kajian seperti lembangan sungai, bukit bukau, hutan, tanah pamah dan tasik. Makalah ini cuba memaparkan secara tuntas dapatan kajian geolinguistik di sepanjang Lembangan Sungai Terengganu (LST). Perbincangan kajian ini memperlihatkan keterkaitan antara aspek variasi bahasa dengan faktor geografi atau reruang.

Malaysia mempunyai beberapa lembangan dan saliran sungai. Sungai Terengganu merupakan antara sungai yang terbesar dan terpanjang di negeri Terengganu. Berdasarkan Senarai Lembangan Sungai bagi Negeri Terengganu, LST mempunyai keluasan 4,595,996 km² (Maklumat Asas Sumber Asli dan Alam Sekitar). LST mengairi kawasan pedalaman hulu iaitu di Tasik Kenyir hingga ke hilir Kuala Terengganu. Pembinaan Empangan Jenagor yang siap pada tahun 1986 telah mewujudkan Tasik Kenyir yang menenggelami beberapa batang sungai yang sedia ada, bukit-bukit serta tanah tinggi juga tenggelam, namun puncak-puncak yang melebihi 
138 meter tingginya telah muncul sebagai pulau-pulau yang menghiasi perairan Tasik Kenyir (Lembaga Kemajuan Terengganu Tengah).

Selain itu LST merupakan antara kawasan terpenting di negeri Terengganu kerana kedudukan lembangan sungai ini yang menghubungkan kedua-dua buah daerah iaitu daerah Hulu Terengganu (HT) dan Kuala Terengganu (KT). Di sepanjang LST ini juga terdapatnya dua buah bandar yang dibina di kawasan muara sungai tersebut iaitu bandar KT yang terletak di daerah KT (di hilir LST) dan bandar Kuala Berang yang terletak di daerah HT (di hulu LST).

Daerah KT adalah bersempadan dengan daerah Setiu di bahagian utara dan barat laut. Di bahagian selatan pula daerah KT bersempadan dengan daerah Marang dan HT. Daerah ini juga terletak berhampiran di pesisir pantai Laut China Selatan di sebelah timur. Terdapat 20 buah mukim di KT iaitu Bandar, Losong, Paloh, Cabang Tiga, Kubang Parit, Bukit Besar, Batu Buruk, Kuala Ibai, Cendering, Pengadang Buluh, Atas Tol, Gelugor Kedai, Gelugor Raja, Tok Jamal, Kepong, Rengas, Serada, Pulau-pulau, Manir dan Belara. Dua buah mukim yang paling berkait erat dengan LST adalah mukim Cabang Tiga dan Manir.

Daerah HT pula merupakan daerah yang bersempadan dengan negeri Pahang di bahagian barat, daerah Besut dan Setiu di bahagian utara, Marang di timur dan Dungun di bahagian selatan. Daerah ini merupakan daerah yang terbesar berbanding daerah-daerah lain yang terdapat di negeri Terengganu. Hal ini kerana daerah tersebut mencatatkan keluasan sebesar 387,462.60 hektar dan memiliki penduduk tempatan seramai 82,700 termasuk penduduk berketurunan Melayu, Bumiputera, Cina, India dan bukan warganegara (Majlis Daerah Hulu Terengganu).

Dari segi bentuk geografi di daerah ini kebanyakan hutan masih terpelihara atau dengan kata lainnya belum diterokai. Bentuk geografi di hulu agak berbeza jika dibandingkan dengan keadaan di hilir. Hal ini kerana di HT terdapat banyak kawasan yang berbukit-bukau dan bergunung-ganang terutamanya kawasan-kawasan yang berhampiran dengan mukim Jenagor dan Tasik Kenyir. Terdapat sembilan buah mukim di HT iaitu Kuala Berang, Hulu Berang, Penghulu Diman, Tanggul, Kuala Telemong, Hulu Telemong, Tersat, Jenagur dan HT.

Dialek Melayu Terengganu (DMT) merupakan variasi Bahasa Melayu dan dialek asas bagi orang Terengganu. Dalam kajian ini DMT dipilih kerana dialek ini diyakini mempunyai kepelbagaian varian atau subdialek yang unik dan tersendiri. Selain itu, varian DMT ini dapat diserlahkan dari aspek leksikal yang dituturkan oleh orang Melayu Terengganu. Kajian ini juga lebih memfokuskan terhadap varian dialek yang dituturkan oleh orang Melayu Terengganu yang tinggal di sepanjang LST. Hal ini kerana dari segi sejarah, kawasan pesisiran atau lembangan sungai adalah asas ketamadunan dialek asal dan jaringan dialek. Maka kajian ini dimulakan dari bahagian hulunya yang terletak di daerah HT hingga ke bahagian hilirnya yang terletak di daerah KT.

\section{Ulasan kosa ilmu kajian lepas}

Menurut Shahidi et al., (2019) DMT merupakan bentuk pertuturan standard dan dipercayai dituturkan secara majoriti oleh orang Melayu Terengganu di Kuala Terengganu. Menurut beliau lagi, kewujudan varian dalam dialek Terengganu sememangnya diperakui oleh ahli-ahli linguistik tempatan seperti Ismail (1973), Collins (1983) Asmah (1985), Abdul Hamid (1990), Ajid (1997), Noraien et al., (2013), Noor Rohana et al., (2013) dan Shahidi et al., (2018).

Sebelum kemunculan awal kajian dialek Melayu oleh pengkaji tempatan seperti Ismail (1973), sudah wujud beberapa kajian yang diusahakan oleh pengkaji Barat seperti Hervey 
(1881), Mckerron (1931) dan Brown (1935) yang menyentuh secara ringkas tentang keberadaan dialek Terengganu. Namun perbincangan mereka tidak begitu meluas dan mendalam. Misalnya, kajian yang dilakukan oleh Mckerron (1931) yang hanya terbatas terhadap kajian tentang keistimewaan dialek Terengganu dari aspek perbendaharaan kata sahaja. Segala data leksikal dalam kajian ini dikutip dan dikumpulkan hanya di daerah Besut di mana penduduk bercakap hampir dengan dialek Kelantan tulen. Begitu juga halnya dengan kajian Brown (1935). Kajian ini hanya dipenuhi dengan catatan berupa dialog yang mengandungi pelbagai kata dan ciri sebutan yang terdapat dalam pertuturan dialek Terengganu. Bagaimanapun usaha awal pengkaji barat ini sedikit sebanyak memberi sumbangan besar terhadap asas permulaan, pembinaan dan perkembangan bidang kajian dialek di Malaysia khususnya kajian dialek di negeri Terengganu.

Kajian Asmah (1977) merupakan antara kajian yang terawal membincangkan kepelbagaian fonologi dialek-dialek Melayu di Semenanjung Malaysia. Berdasarkan kajian ini beliau berjaya membahagikan kelompok dialek-dialek Melayu di Semenanjung kepada empat jenis kelompok iaitu kelompok Barat Laut (terdiri daripada kelompok Kedah, Perlis, Pinang meliputi Perak utara), kelompok Timur Laut (dialek Kelantan), Kelompok Timur (dialek Terengganu) dan kelompok Selatan (Johor, Melaka, Pahang, Selangor dan Perak di selatan). Kajian ini agak umum dan tidak begitu terperinci dalam memerihalkan keberadaan dialek di negeri Terengganu. Kajian Asmah (1977) merupakan kajian yang terbatas terhadap pemerian fonologi yang dibandingkan antara dialek-dialek Melayu yang terdapat di Semenanjung Malaysia.

Kajian Collins (1983) pula merupakan kajian geografi dialek yang menyentuh aspek fonologi bagi varian dialek yang terdapat di Hulu Terengganu. Kajian ini membuktikan bahawa di Hulu Terengganu mempunyai pelbagai varian-varian dialek yang berbeza. Akan tetapi kajian ini dilakukan secara terbatas di LST kerana penelitiannya hanya berfokus di hulu semata-mata. Beliau juga membatasi kajian tentang aspek fonologi (iaitu melibatkan sistem vokal, konsonan dan diftong), morfologi dan sintaksis. Memandangkan fokus kajian Collins agak terbatas, maka varian DLST di sepanjang LST harus diusahakan yakni bermula di hulu, tengah dan hilir lembangan sungai tersebut. Aspek pemetaan dan pengelompokan dialek juga wajar diselaraskan dengan pendekatan yang mengaplikasikan perisian 'Geographical Information System' untuk menghasilkan pemetaan linguistik yang lebih tepat, berdigital, moden dan berkontemporari.

Kajian Ajid (1997) membicarakan tentang perubahan bunyi yang berlaku di akhir kata yang terdapat dalam dialek-dialek Melayu di Malaysia. Kajian ini lebih menumpukan kajian linguistik berdasarkan aspek fonologi, morfologi, sintaksis dan leksikal yang terdapat dalam ujaran penutur Besut. Keterbatasan kajian ini terserlah kerana ia hanya bertumpu di bahagian utara negeri Terengganu iaitu di Besut yang mana kebanyakannya menggunakan dialek Kelantan. Ajid (2008) turut membuat perbandingan antara dialek Kelantan dengan dialek Terengganu (didasarkan kepada varian yang digunakan di Kampung Tok Dir, Bukit Payung, Kuala Terengganu). Kajian ini sebenarnya lebih bertujuan untuk mencari salasilah bahasa yang berpedomankan kerangka bidang linguistik sejarah.

Kajian berkaitan dialek Terengganu turut disentuh oleh Noraien et al., (2013). Ia adalah satu kajian linguistik tentang DMT yang dilakukan di pesisir pantai negeri Terengganu. Berdasarkan penelitian terhadap kajian ini, ternyata bahawa kajian ini terbatas terhadap perbincangan mengenai ciri-ciri linguistik dan kosa kata yang terdapat dalam DMT Pesisir Pantai sahaja iaitu Chendering, Batu Rakit, Chabang Tiga dan Banggol Peradong.

Noor Rohana et al., (2013) juga telah membuat tinjauan terhadap aspek fonologi dan kosa kata yang terdapat dalam DMT. Kajian ini juga dikatakan terbatas kerana kajian ini 
memfokuskan tentang proses menganalisis dan menjelaskan tentang ciri-ciri keunikan dialek negeri Terengganu serta strategi pengekalan warisan variasi bahasa tempatan dalam konteks penggunaan bahasa lokaliti daerah pesisir pantai. Kajian ini menunjukkan tentang keunikan DMT di kawasan pesisir pantai yang mana mempunyai ciri-ciri yang tersendiri sama ada dari aspek fonologi dan kosa kata dalam pertuturan dialek tersebut. Sebagai contoh beliau menyentuh tentang kelainan sebutan bagi aspek bunyi vokal, konsonan, diftong, suku kata dan kosa kata yang melibatkan proses pengguguran, penggantian, pemendekan, penegasan sebutan, perkataan serta pengayaan kosa kata tempatan.

Kajian lepas berkaitan variasi dialek di Terengganu telah memfokuskan aspek fonologi, morfologi, sintaksis, leksikal serta kajian mengenai susur galur atau perkembangan bahasa. Terdapat juga kosa kajian lepas yang bersifat dialektologi geografi atau geografi dialek. Kajiankajian lepas ternyata lebih bersifat tradisional iaitu tanpa penglibatan kaedah Sistem Maklumat Geografi (GIS). Berdasarkan penelitian terhadap kajian lepas, jelas didapati bahawa kajiankajian dialek di negeri Terengganu masih belum diterokai sepenuhnya, khususnya tentang keberadaan varian DLST di sepanjang LST. Hal ini kerana Terengganu mempunyai pelbagai variasi dialek yang berbeza-beza jika hendak dibandingkan dengan dialek-dialek Melayu yang terdapat di negeri lain. Tinjauan kosa ilmu telah memberikan satu gambaran tentang keterbatasan dan kelompongan kajian-kajian lepas khususnya dari segi metodologi yang digunakan, serta kawasan dan dapatan kajian yang begitu umum dan ringkas.

Makalah ini bertujuan untuk membina peta variasi DLST yang wujud di LST. Secara khusus, objektif kajian ini ialah; i) menyerlahkan bilangan variasi leksikal 'aku', 'kamu' dan 'mereka' yang digunakan oleh penutur di sepanjang Lembangan Sungai Terengganu, dan ii) menghasilkan peta isoglos varian Dialek Lembangan Sungai Terengganu di sepanjang Lembangan Sungai Terengganu menggunakan GIS.

\section{Metod kajian}

Daerah yang menjadi tapak lokasi mendapatkan data varian DLST adalah daerah KT dan HT. Kedua-dua daerah ini dihubungkan dengan satu lembangan sungai iaitu LST. Titik pengamatan kajian bermula di mukim Cabang Tiga, daerah KT hingga ke mukim Jenagor, daerah HT. Beberapa buah mukim di kedua-dua buah daerah dipilih kerana berasaskan kepada aliran LST.

Kajian ini tertumpu kepada kampung-kampung dalam mukim yang berkaitan dengan LST iaitu Kg. Makam Lama (KML), Kg. Pasir Tebakang (KPT), Kg. Padang Macang (KPM), Kg. Pulau Manis (KPMS), Kampung Baung (KBAU), Kampung Payang Kayu (KPK), Kampung Dusun (KDSN), Kampung Bidur (KBDR), Kampung Pauh (KPAU), Kampung Pasir Nering (KPN), Kampung Gaung (KGG), Kampung Butut (KBTT), Kampung Tajin (KTJN), Kampung Pulau Kudat (KPKD), Kampung Sungai Ular (KSU), Kampung Nasi Dingin (KDN), Kampung Chepoh (KCPH), Kampung Tok Imam Lapar (KTIL), Kampung Jenagor (KJNG), Kampung Dura (KDRA) dan Kampung Kuala Pueh (KKPH).

Seramai 30 orang informan telah dipilih untuk ditemu bual bagi mendapatkan data pertuturan asli dan tulen. Kesemua informan ini memiliki tubuh badan sihat dan tiada kecacatan pendengaran dan pertuturan. Pemilihan informan dari kawasan tengah dan hulu LST lebih diutamakan kerana maklumat awal (menerusi wakil informan dan tinjauan awal) menunjukkan bahawa kawasan hilir tidak menampakkan kewujudan kelainan varian berbanding kawasan 
tengah dan hulu LST. Kriteria-kriteria pemilihan informan ini adalah merujuk kepada istilah NORM/F iaitu Non-mobile, Old, Rural dan Male/Female.

Perisian GIS dimanfaatkan sepenuhnya untuk memproses, menganalisis dan menafsir data yang diperoleh di lapangan. Menurut Ang (2015) GIS ditakrifkan sebagai satu sistem untuk menangkap, menyimpan, memeriksa, mengintegrasikan, memanipulasikan, menganalisis dan memaparkan data yang berkaitan dengan reruang yang berpandukan kepada bumi. Secara umumnya penggunaan sistem ini adalah untuk menghasilkan pemetaan secara berdigital dan bermaklumat. Hal ini kerana pemetaan secara berdigital ini bersifat tepat, jelas dan benar jika hendak dibandingkan dengan kaedah pemetaan yang dilakukan secara tradisional. Bagi menghasilkan peta digital data mentah yang diperoleh di lapangan perlu ditukar ke dalam bentuk digital supaya dapat diproses secara langsung melalui komputer.

Secara umumnya sebarang kewujudan penyebaran dan kesejajaran leksikal varian DLST di sepanjang LST pastinya memiliki keterikatan dengan faktor geografi dan keadaan semula jadi di kawasan berkenaan. Hakikatnya, pengaplikasian GIS menggabungkan dan memanfaatkan maklumat dua bidang ilmu iaitu linguistik dan geografi. Perisian tersebut memainkan fungsi penting dalam menggabungkan data linguistik yang diperoleh melalui kajian lapangan dengan alat analisis Spatial (lihat juga, Mohamad Firdaus, 2020).

Sebelum penghasilkan peta isoglos varian DLST dilakukan, aktiviti pemetaan kloroplet telah dijalankan sebagai proses awal menganalisis GIS data linguistik varian DLST di sepanjang LST. Peta kloroplet berfungsi untuk mengenalpasti taburan data linguistik di setiap kawasan kajian. Taburan data linguistik ini dapat ditonjolkan melalui perletakan pelbagai simbol yang mewakili sesuatu data dan kampung kajian. Oleh itu, berdasarkan peta-peta kloroplet inilah maka penghasilan peta-peta isoglos dapat dibina bagi membuktikan gejala persebaran varian DLST di sepanjang LST berasaskan garis-garis isoglos yang terhasil.

Isoglos bererti garis sempadan dialek. Menurut Chambers dan Trudgill (1990) isoglos ditakrifkan sebagai sempadan antara dua kawasan yang berbeza dari segi ciri bahasa tertentu seperti item leksikon atau persebutan perkataan tertentu dan sebagainya. Dengan menentukan ciri-ciri bahasa inilah maka seseorang pengkaji itu boleh menghasilkan peta atau atlas dialek yang menunjukkan pengelompokan dan pembahagian ciri-ciri dialek mengikut kawasan.

Pemetaan isoglos diusahakan bagi menggambarkan ciri-ciri varian DLST yang dikaji di sepanjang LST. Pemetaan isoglos ini dibina berasaskan analisis variasi tiga leksikal 'aku', 'kamu' dan 'mereka'. Pemilihan tiga leksikal ini dapat menjelaskan kewujudan varian-varian di kawasan berkenaan. Hal ini kerana leksikal yang dipilih merupakan leksikal harian yang sering digunakan oleh penduduk kampung dan juga mempunyai hubungan keakraban dengan masyarakat setempat. Oleh itu dengan menganalisis leksikal 'aku', 'kamu' dan 'mereka' maka ianya dirasakan berpada untuk memaparkan keistimewaan bagi varian DLST yang ditemui di sepanjang LST.

Peta isoglos akan dipaparkan bagi menyerlahkan perbezaan varian-varian mengikut zonzon atau ciri-ciri kawasan tertentu. Penggunaan istilah zon-zon atau ciri-ciri kawasan adalah bertujuan untuk menunjukkan varian-varian yang wujud secara nyata di sesebuah kawasan kajian. Misalnya Zon A atau Ciri Kawasan A menunjukkan pembahagian dan pengelompokan bagi varian A, Zon B atau Ciri Kawasan B pula merupakan pembahagian dan pengelompokan bagi varian B dan begitulah keadaan yang selanjutnya. Pemetaan isoglos ini, justeru, menggunakan perlabelan 'Ciri Kawasan' bagi menggambarkan pembahagian dan pengelompokan sesuatu varian dialek. Penggunaan label ini adalah cukup lazim digunakan oleh penyelidik-penyelidik, misalnya Rohani Mohd. Yusof (2003) dan Habibah Che Rosdi (2016). 
Dapatlah ditegaskan di sini bahawa kajian ini menekankan aspek pembinaan peta isoglos. Hal ini sangat penting kerana bahagian inilah yang membuktikan peranan GIS yang diterapkan dalam kajian ini. Peta-peta isoglos dapat memaparkan beberapa maklumat yang lebih khusus berkenaan kawasan kajian dan kaitannya dengan penyebaran varian DLST yang wujud di sepanjang LST. Nama-nama kampung yang terpilih dalam sesuatu daerah akan dimasukkan mengikut titik koordinat longitud dan latitud yang tepat. Di samping itu, aspek geografi seperti lambang bukit bukau dan sungai turut dipaparkan mengikut kepanjangan dan lokasi yang tepat.

Penelitian varian DLST ini adalah berasaskan variasi leksikal 'aku', 'kamu' dan 'mereka'. Penganalisisan data kajian ini masih berpandukan bidang kajian geografi dialek terdahulu sepertimana yang dilakukan oleh Ajid (1997) dan Habibah Che Rosdi (2016). Cuma, bidang ini dimajukan lagi menerusi pengkaedahan teknologi terkini iaitu dengan penggunaan aplikasi GIS agar bidang geografi dialek tradisional ini mengalami kemodenan yang tersendiri dan juga memberikan satu kajian yang bersifat terkini.

\section{Dapatan kajian}

Berdasarkan daripada analisis data kajian, dapatlah diserlahkan di sini keragaman varian DLST. Varian DLST dapat dikategorikan kepada lapan kawasan yang utama berdasarkan ciri-ciri tertentu sepertimana yang dipaparkan dalam peta dan huraian seterusnya.

Rajah 1 menunjukkan pengelompokan dan pembahagian varian DLST di sepanjang LST. Terdapat sebanyak lapan ciri yang menentukan varian DLST yang ditemui di sepanjang lembangan sungai tersebut iaitu Ciri A, Ciri B, Ciri C, Ciri D, Ciri E, Ciri F, Ciri G, dan Ciri H. Ciri A yang berwarna $\square$ adalah pertuturan varian Makam Lama. Varian Makam Lama ini tersebar di bahagian hilir lembangan sungai (di sekitar daerah Kuala Terengganu) dan persisiran pantai. Penyebaran varian ini berlaku di KML, KPM, KPT dan KPMS. Penduduk kampung tersebut menggunakan leksikal seperti [ambə] [mun] dan [muy səmə] dalam komunikasi seharian mereka.

Ciri B pula yang ditandai dengan warna $\square$ adalah mewakili varian Tajin. Varian ini dilihat tersebar di bahagian tengah LST dan varian ini jelas ditemui di daerah Hulu Terengganu. Penduduk kampung yang berasal dari KTIL, KCPH, KND, KSU, KPKD dan KTJN yang sering menggunakan leksikal seperti [akuw ${ }^{\mathrm{w}}$ [muy] dan [dimə].

Isoglos seterusnya adalah Ciri C. Ciri C yang berwarna $\square$ adalah menunjukkan bahawa varian Butut tersebar di tengah LST dan penyebaran ini berlaku dalam mukim Kuala Berang. Varian ini dikenal pasti menerusi analisis dan dapatan kajian tentang penyebaran varian $\left[\mathrm{aku}^{\mathrm{w}}\right]$ [mun] dan [demə]. Leksikal-leksikal tersebut mudah dijumpai dalam pertuturan penduduk di KBTT, KGG dan KPN.

Ciri $\mathrm{D} \square$ dan E $\square$ menunjukkan penyebaran varian dialek yang terhad dan terbatas kepada satu buah kampung sahaja. Ciri D adalah ciri varian Pauh. Ciri D ini terbukti memiliki varian DLST yang unik kerana ramai dalam kalangan penutur yang merupakan penduduk asal di KPAU menggunakan leksikal [akow?] [mike] dan [muwi] dalam komunikasi seharian mereka. Manakala Ciri E pula menunjukkan penyebaran leksikal [nək $\left.{ }^{\mathrm{w}}\right]\left[\mathrm{mu}^{\mathrm{w}}\right]$ dan [dime] bagi varian Bidur. Varian ini hanya dijumpai di KBDR.

Selanjutnya varian Kuala Pueh yang ditandai dengan warna $\square$ bagi Ciri F adalah satu bentuk pertuturan yang dituturkan oleh penduduk asal KKPH dan KDR. Penduduk kampung tersebut menggunakan leksikal yang tersendiri seperti leksikal [aku ${ }^{\mathrm{w}}$ ] [mun] dan [dime]. 


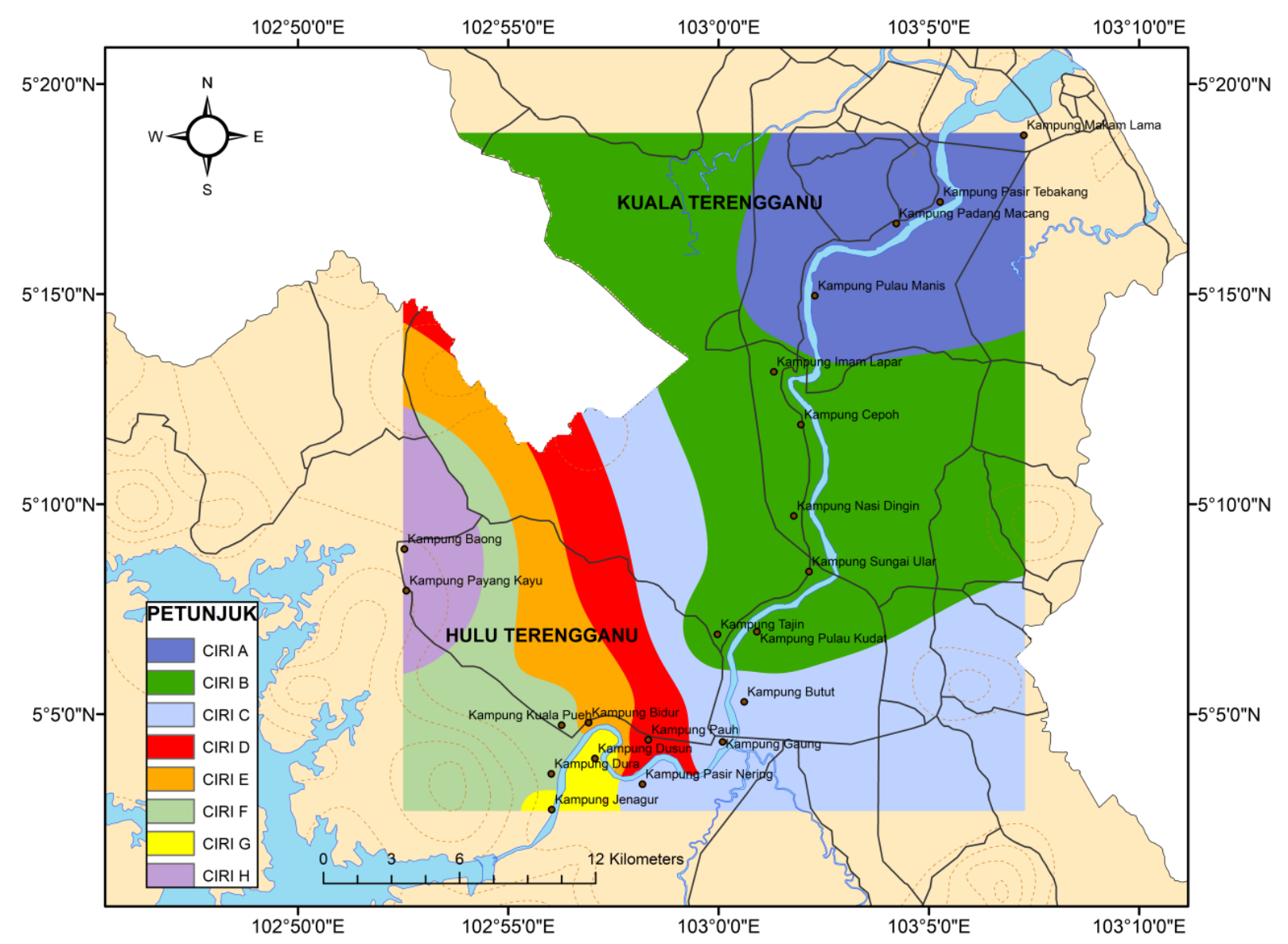

Rajah 1. Peta Isoglos Varian Dialek Lembangan Sungai Terengganu di sepanjang Lembangan Sungai Terengganu

Selain itu, dua lagi varian DLST turut ditemui iaitu varian Jenagor dan Baung di hulu LST. Varian Jenagor merupakan bentuk pertuturan dialek yang dituturkan di kawasan Ciri G . Varian ini dapat dikesan berlaku di kampung-kampung yang terletak di hujung hulu LST dan juga jauh dipedalaman kampung. Antara kampung-kampung yang terlibat seperti KDSN dan KJNG. Varian ini sangat unik kerana ramai dalam kalangan penduduk yang berasal dari keduadua buah kampung tersebut lebih gemar menggunakan leksikal seperti $\left[\mathrm{ak} \jmath^{\mathrm{w}}\right][\mathrm{mik} \varepsilon]$ dan $[\operatorname{dim} \varepsilon]$ bagi rujukan diri.

Ciri $\mathrm{H}$ yang merupakan ciri terakhir pula menandai isoglos varian Baung. Ciri $\mathrm{H}$ yang diwarnakan dengan warna $\square$ sememangnya mempunyai varian DLST yang sangat istimewa. Varian ini hanya boleh dijumpai di kampung-kampung yang terletak di pesisiran tasik, berhampiran hulu sungai, kawasan berbukit dan berhutan tebal. Ramai dalam kalangan penduduk KPK dan KBAU menggunakan leksikal seperti [akə?] [mən] dan [dimi] sebagai leksikal seharian mereka. Jadual 1 menyenaraikan tentang pengelompokan dan pembahagian lapan varian DLST di sepanjang LST. 
Jadual 1. Pengelompokan dan pembahagian varian dialek Lembangan Sungai Terengganu di sepanjang Lembangan Sungai Terengganu

\begin{tabular}{|c|c|c|c|c|c|c|c|c|}
\hline Ciri & $\mathbf{A}$ & B & $\mathbf{C}$ & D & $\mathbf{E}$ & $\mathbf{F}$ & $\mathbf{G}$ & $\mathbf{H}$ \\
\hline Varian & $\begin{array}{l}\text { Makam } \\
\text { Lama }\end{array}$ & Tajin & Butut & Pauh & Bidur & $\begin{array}{l}\text { Kuala } \\
\text { Pueh }\end{array}$ & Jenagor & Baung \\
\hline Kampung & $\begin{array}{l}\text { KML } \\
\text { KPM } \\
\text { KPT } \\
\text { KPMS }\end{array}$ & $\begin{array}{l}\text { KTIL } \\
\text { KCPH } \\
\text { KND } \\
\text { KSU } \\
\text { KPKD } \\
\text { KTJN }\end{array}$ & $\begin{array}{l}\text { KBTT } \\
\text { KGG } \\
\text { KPN }\end{array}$ & KPAU & KBDR & $\begin{array}{l}\text { KKPH } \\
\text { KDR }\end{array}$ & $\begin{array}{l}\text { KDSN } \\
\text { KJNG }\end{array}$ & $\begin{array}{l}\text { KPK } \\
\text { KBAU }\end{array}$ \\
\hline $\begin{array}{l}\text { Data } 1 \\
\text { 'aku' }\end{array}$ & [ambə] & {$\left[\mathrm{aku}^{\mathrm{w}}\right]$} & {$\left[\mathrm{aku}^{\mathrm{w}}\right]$} & [akow? & {$\left[\mathrm{n} ə \mathrm{~kg} \mathrm{w}^{\mathrm{w}}\right]$} & {$\left[\mathrm{aku}^{\mathrm{w}}\right]$} & {$\left[\mathrm{akg}{ }^{\mathrm{w}}\right]$} & [akə?] \\
\hline $\begin{array}{l}\text { Data } 2 \\
\text { 'kamu', }\end{array}$ & [muy] & [muy] & [muy] & [mike] & {$\left[\mathrm{mu}^{\mathrm{w}}\right]$} & [muy] & [mike] & [məy] \\
\hline $\begin{array}{l}\text { Data } 3 \\
\text { 'mereka' }\end{array}$ & $\begin{array}{l}\text { [muy } \\
\text { səmə] }\end{array}$ & [dimə] & [demə] & [muwi] & {$[\operatorname{dim} \varepsilon]$} & [dime] & {$[\operatorname{dim} \varepsilon]$} & [dimi] \\
\hline
\end{tabular}

\section{Pemetaan isoglos variasi tiga leksikal varian DLST}

Berdasarkan pemaparan rajah 1, pengelompokan dan pembahagian ciri-ciri varian dialek yang ditemui merupakan hasil kombinasi peta-peta isoglos bagi variasi leksikal 'aku', 'kamu' dan 'mereka'. Pemilihan ketiga-tiga leksikal tersebut dilihat bervariasi, tulen dan sering diguna pakai dalam komunikasi seharian oleh masyarakat kampung di kawasan kajian. Berikut merupakan pemaparan peta isoglos bagi variasi leksikal 'aku', 'kamu' dan 'mereka'yang terdapat di sepanjang LST.

\section{Variasi Leksikal 'aku'}

Berdasarkan rajah 2, didapati bahawa variasi bagi leksikal 'aku' ternyata membuktikan kepelbagaian realisasi sebutannya dalam kalangan penduduk kampung di sepanjang LST. Antara varian yang ditemui termasuklah [ambə], [aku $\left.{ }^{\mathrm{w}}\right],\left[\mathrm{ak} \jmath^{\mathrm{w}} \mathrm{P}\right],\left[\mathrm{nək}^{\mathrm{w}}\right],\left[\mathrm{ak} \jmath^{\mathrm{w}}\right]$ dan [akə?]. Varian [ambə] yang berwarna $\square$ menunjukkan varian Makam Lama iaitu varian DLST yang dituturkan di hilir LST. Varian ini ditemui di KML, KPM, KPT dan KPMS. Di tengah LST pula ramai penduduk kampung menggunakan leksikal $\left[\mathrm{aku}^{\mathrm{w}}\right]$ yang ditandakan dengan warna Sebanyak lapan buah kampung yang menggunakan varian [aku ${ }^{\mathrm{w}}$ ] iaitu KTIL, KCPH, KND, KSU, KPKD, KTJN, KBTT, KGG, KPN, KKPH dan KDR.

Selain itu varian $\left[\right.$ nək $\left.\vartheta^{\mathrm{w}}\right]$ yang diwarnakan $\square$ dianggap unik kerana hanya dituturkan oleh penduduk yang berasal di KBDR sahaja. Begitu juga dengan varian [ak ${ }^{\text {w? }}$ ] yang diwarnakan $\square$ hanya dituturkan oleh penduduk yang berasal di KPAU. Berbeza pula varian leksikal 'aku' yang digunakan oleh penduduk di KDSN dan KJNG. Hal ini kerana kebanyakan penduduk di kedua-dua buah kampung merealisasikan varian [ak $\left.{ }^{\mathrm{w}}\right]$ yang mana varian tersebut diwarnakan dengan $\square$. Keunikan variasi leksikal 'aku' yang terakhir ialah varian [akə?] yang ditandai dengan warna

Varian ini sering digunakan oleh penduduk kampung yang berasal dari KPK dan KBAU. Varian [akə?] ini juga merupakan sebutan asli oleh penduduk yang tinggal jauh pedalaman hulu kampung. 


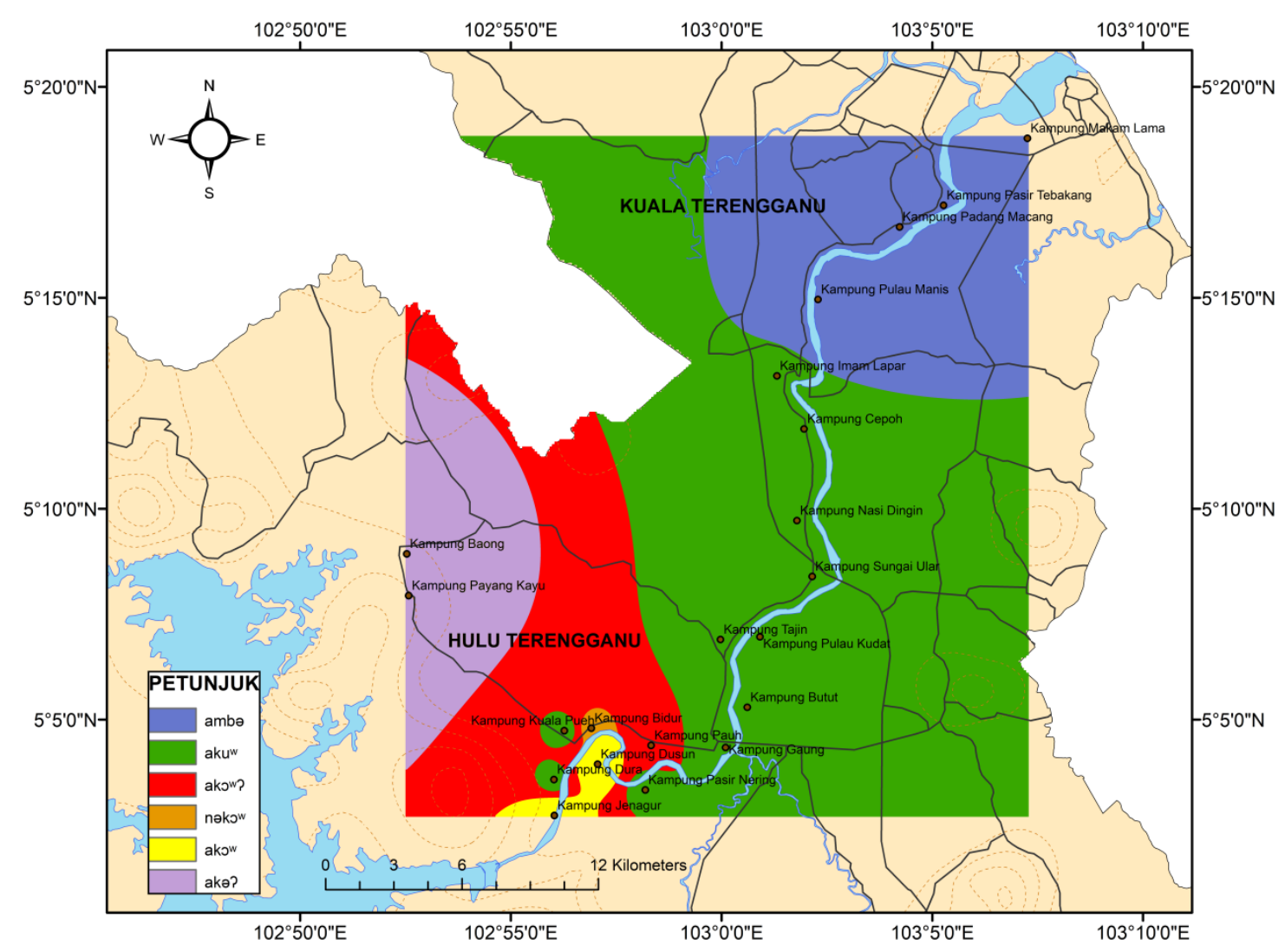

Rajah 2. Peta isoglos variasi leksikal 'aku'

\section{Variasi Leksikal 'kamu'}

Taburan variasi leksikal 'kamu' telah membentuk sebuah peta isoglos yang begitu rencam (Rajah 3). Variasi leksikal 'kamu' jelas didapati mempunyai kepelbagaian variasi leksikalnya di sepanjang LST. Antara variasi yang ditemui termasuklah [muy], [mike], [muw ] dan [məy]. Secara umumnya varian [muy] yang ditandai dengan warna $\square$ adalah varian majoriti dan sangat bersinonim dengan pertuturan DMT. Varian ini tersebar dari KML sehingga ke KDR. Varian [mike] pula yang seolah-olah menyamai Dialek Perak sering digunakan oleh penduduk yang berasal dari KPAU, KDSN dan KJNG. Varian [mike] yang diwarnakan dengan menunjukkan bahawa tidak ada sebarang penyebaran atau pengaruh Dialek Perak di kawasan kajian. Hal ini kerana ramai dalam kalangan penduduk di kawasan kajian tersebut adalah anak jati negeri Terengganu.

Selain itu varian $\left[\mathrm{mu}^{\mathrm{w}}\right]$ yang diwarnakan dengan warna $\square$ menunjukkan bahawa varian tersebut adalah terbatas kepada satu buah kampung sahaja iaitu KBDR. Seterusnya bagi KPK dan KBAU pula memperlihatkan keunikan leksikal 'kamu' yang tersendiri. Kedua-dua buah kampung kajian merealisasikan leksikal 'kamu' sebagai varian [məy] yang ditandai dengan warna $\square$. Tidak dinafikan bahawa kedua-dua buah kampung tersebut mempunyai jarak yang agak berdekatan dan boleh dikatakan terasing jauh dari Bandar Kuala Berang. 


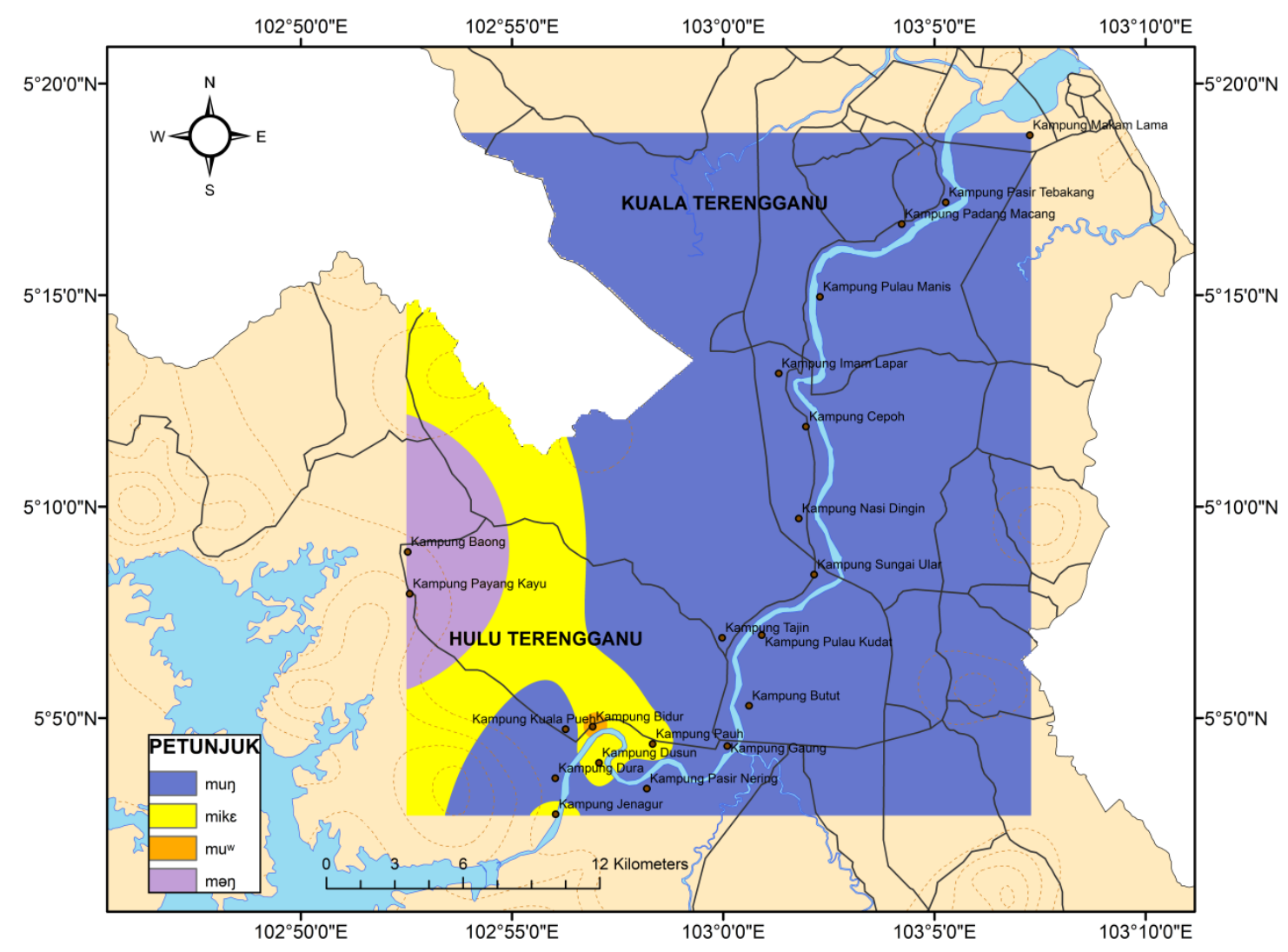

Rajah 3. Peta isoglos variasi leksikal 'kamu'

\section{Variasi Leksikal 'mereka'}

Terdapat tujuh penggunaan variasi leksikal 'mereka' iaitu [muy səmə], [dimə], [demə], [muwi], [dime], [dime] dan [dimi] (Rajah 4). Varian [muy səmə] yang dipaparkan dengan warna $\square$ menunjukkan penyebaran varian tersebut berlaku di KML sehingga ke KPMS. Di tengah LST pula ramai dalam kalangan penduduk kampung yang merealisasikan varian [dimə]. Varian [dimə] yang ditandakan dengan warna $\square$ sering digunakan oleh penduduk kampung yang berasal dari KTIL, KCPH, KND, KSU, KTJN dan KPKD. Varian [demə] yang ditandai dengan warna $\square$ pula menunjukkan varian ini tersebar dari KBTT hingga ke KPN. Varian [muwi] yang diwarnakan dengan warna $\square$ hanya dituturkan oleh penduduk kampung yang berasal dari KPAU sahaja.

Selain itu varian [dime] yang ditandai warna $\square$ digunakan oleh penduduk kampung yang tinggal di KDSN dan KJNG. Bagaimanapun varian [dime] merupakan varian yang digunakan oleh penduduk kampung yang tinggal di KKPH dan KDR. Varian tersebut ditandakan dengan warna $\square$ menunjukkan penyebaran leksikal yang tidak begitu meluas dan terbatas. Begitu juga dengan KPK dan KBAU yang mana penduduknya sering menggunakan varian [dimi] seperti yang dipaparkan dengan warna 


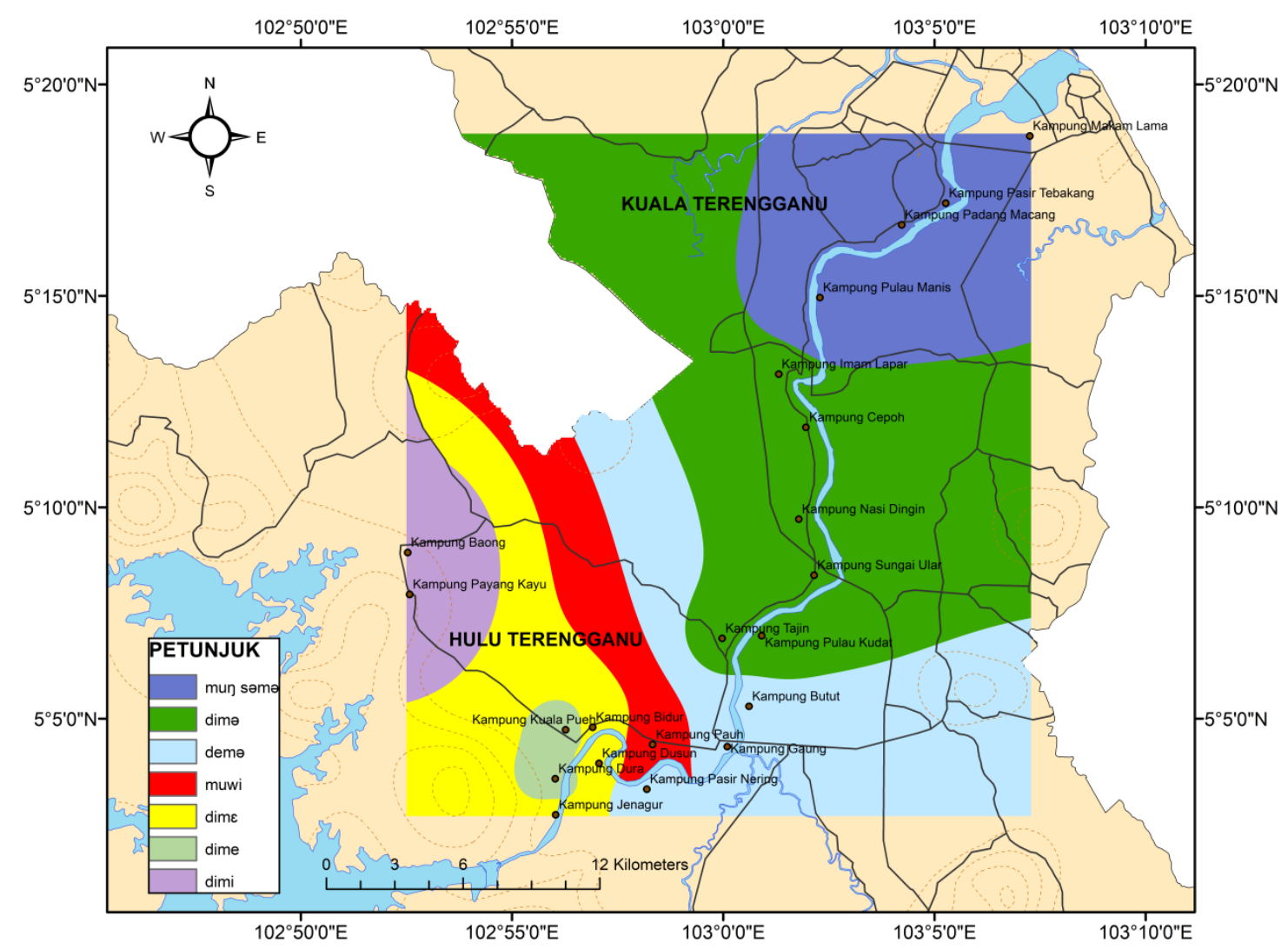

Rajah 4. Peta isoglos variasi leksikal 'mereka'

\section{Varian dialek di Lembangan Sungai Terengganu}

Berdasarkan rajah 1, 2, 3 dan 4, dapat dilihat penyebaran dan kesejajaran leksikal beberapa varian DLST di sepanjang LST. Kedudukan kawasan kajian ini menyebabkan berlakunya perbezaan pertuturan varian DLST berasaskan ruang lingkup geografi di kawasan kajian. Justeru didapati bahawa perbezaan-perbezaan varian DLST yang ditemui di LST adalah disebabkan faktor geografi.

Bagi Mohamad Firdaus (2020), faktor geografi turut mempengaruhi kepelbagaian leksikal di kawasan kajian seperti bentuk muka bumi yang bergunung, serta hutan simpan yang tebal. Sepertimana yang terserlah dalam rajah 5, bentuk muka bumi dan geografi yang penting dalam kajian ini merangkumi lembangan/jaringan sungai, persisiran pantai dan tasik. Bertanah pamah juga merupakan bentuk muka bumi yang dapat memberi kesan terhadap penyebaran sesuatu varian dialek di kawasan kajian. 


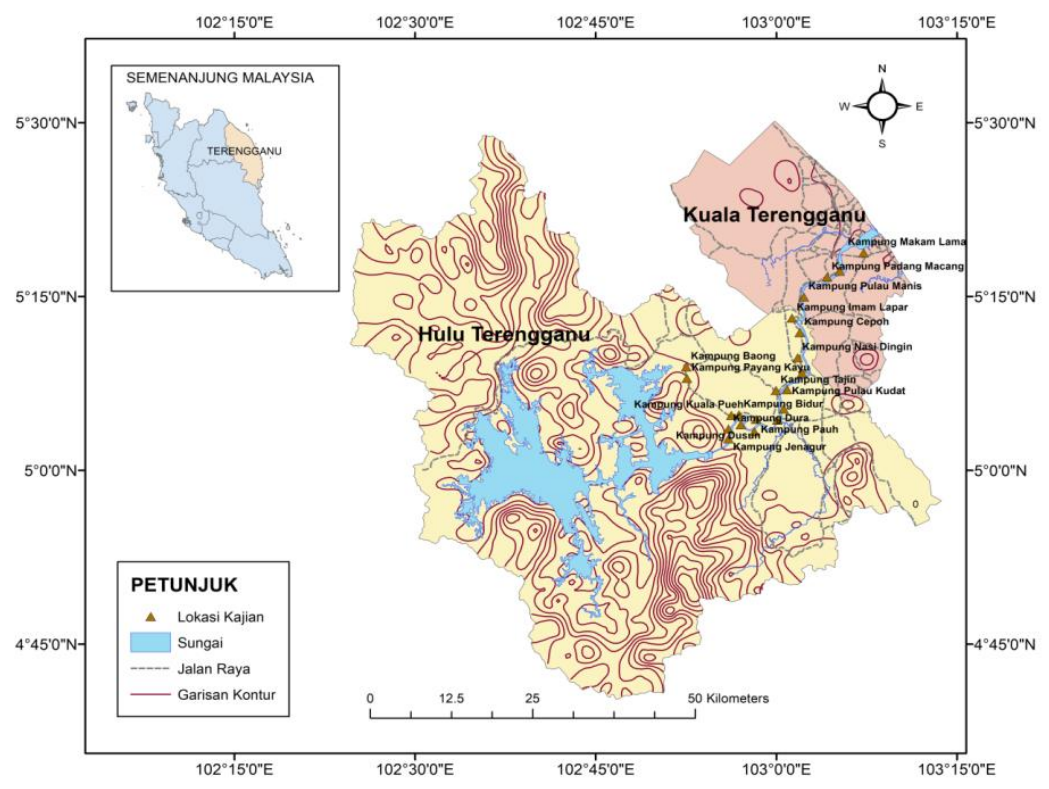

Rajah 5. Bentuk muka bumi kawasan kajian

Menerusi kajian berperingkat di dua buah daerah di sepanjang LST berdasarkan tiga leksikal iaitu /aku/, /kamu/ dan /mereka/, maka dapatlah dikemukakan sebuah peta isoglos varian DLST. Hasil dapatan kajian seperti paparan peta isoglos (Rajah 6) telah menunjukkan bahawa terdapat sebanyak lapan varian DLST yang ditemui di sepanjang LST iaitu varian Makam Lama, varian Tajin, varian Butut, varian Pauh, varian Bidur, varian Kuala Pueh, varian Jenagor dan varian Baung. Pada peta isoglos yang dibina, setiap reruang varian dialek tersebut akan diwarnai dengan warna yang berbeza-beza. Selain itu petunjuk pada bahagian kiri bawah peta pula bertujuan untuk memudahkan perjelasan tentang kewujudan lapan varian DLST yang wujud di sepanjang LST.

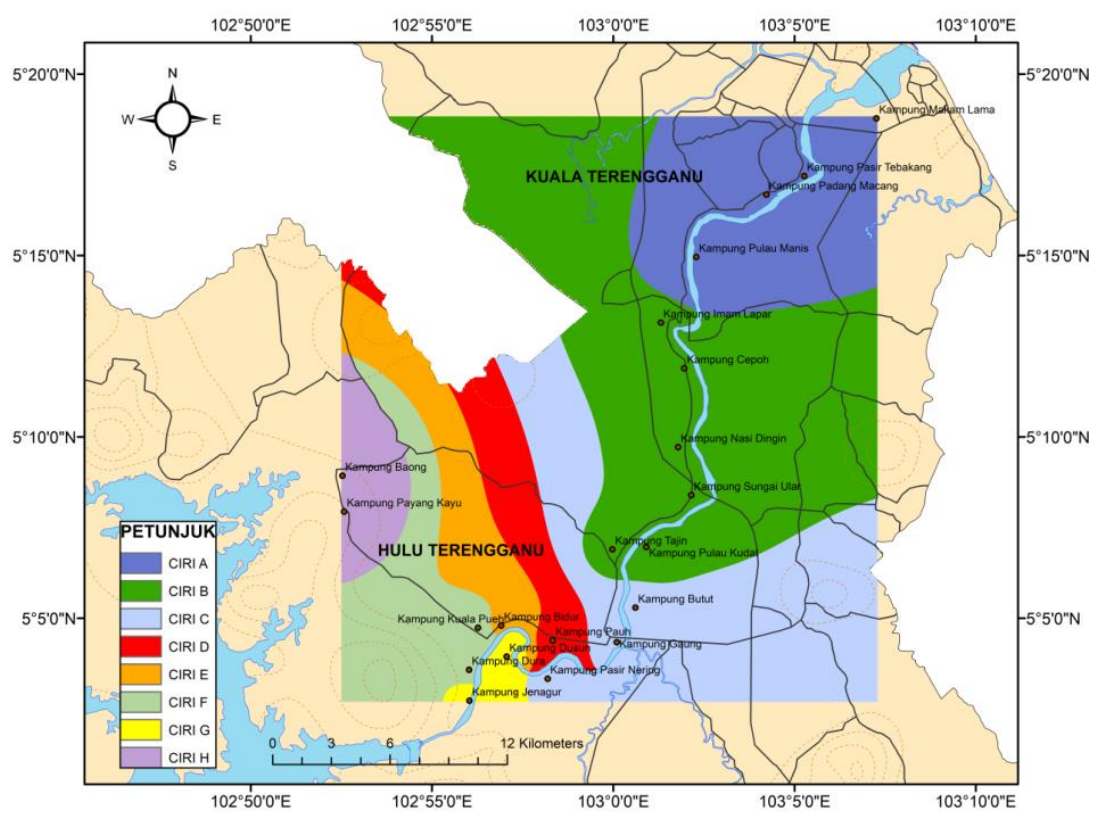

Rajah 6. Peta isoglos lapan varian dialek Lembangan Sungai Terengganu 
Pembinaan peta isoglos (Rajah 6) turut menunjukkan nama-nama kampung yang berkoordinat tepat di samping mengetengahkan aspek geografi seperti lembangan sungai dan bukit bukau. Analisis GIS mampu menghasilkan peta yang memaparkan kawasan yang menuturkan varian leksikal dan rupa bentuk geografi di sesebuah kawasan kajian. Dari sudut geografi penyebaran varian-varian DLST di sepanjang LST boleh dirumuskan seperti berikut;

\section{a. Varian Makam Lama}

Penyebaran varian Makam Lama boleh dikatakan sebagai varian DMT yang asas dituturkan di daerah KT. Penyebaran varian ini berlaku di sekitar hilir lembangan sungai Terengganu yang terletak di daerah KT. Keadaan geografi muka bumi di sekitar kawasan hilir lembangan sungai tersebut adalah tanah pamah dan landai yang memudahkan penyebaran varian Makam Lama berlaku. Kesemua informan daripada kampung kajian di hilir lembangan sungai tersebut menggunakan leksikal /aku/, /kamu/ dan /mereka/ sebagai [ambə], [muy] dan [muy səmə]. Antara kampung yang terlibat ialah KML, KPM, KPT dan KPMS.

\section{b. Varian Tajin}

Varian Tajin mempunyai keistimewaan dari aspek variasi leksikal yang tersendiri. Varian ini dituturkan di daerah HT iaitu di bahagian tengah LST yang mana bentuk muka bumi di kawasan tersebut adalah bertanah pamah dan landai. Keadaan bentuk muka bumi tersebut telah memudahkan penyebaran varian Tajin berlaku. Kesemua kampung kajian di tengah lembangan sungai tersebut (sama ada di kiri atau kanan sungai) menggunakan varian Tajin bagi leksikal /aku/, /kamu/ dan /mereka/ sebagai [akuw ${ }^{\mathrm{w}}$, [muy] dan [dimə]. Antara kampung yang terlibat ialah KTIL, KCPH, KND, KSU, KPKD dan KTJN.

\section{c. Varian Butut}

Varian Butut pula dituturkan di daerah HT. Penyebaran varian dialek ini berlaku di tengah LST. Varian ini mudah tersebar kerana bentuk muka bumi kawasan kajian yang bertanah pamah dan landai. Kesemua kampung kajian di kawasan berkenaan menggunakan varian Butut seperti leksikal /aku/, /kamu/ dan /mereka/ dalam Bahasa Melayu Standard disebut sebagai [akuw], [muy] dan [demə]. Antara kampung yang terlibat ialah KBTT, KGG dan KPN.

\section{d. Varian Pauh}

Varian Pauh merupakan varian dialek yang tersebar di kawasan hulu LST di daerah HT. Namun begitu varian ini agak terhad penyebarannya kerana didapati bahawa kawasan tersebut terletak berhampiran dengan kawasan geografi yang sukar diakses. Antara rupa bentuk geografi yang dimaksudkan adalah seperti hulu sungai, berhutan, bertanah pamah dan juga terletak di pedalaman hulu kampung. Dalam hal ini terdapat satu buah kampung sahaja yang terlibat iaitu KPAU. Kebanyakan informan yang berasal di kampung kajian merealisasikan leksikal /aku/, /kamu/ dan /mereka/ dalam Bahasa Melayu sebagai [akow? ${ }^{\mathrm{w}}$, [mike] dan [muwi]. 


\section{e. Varian Bidur}

Varian Bidur adalah sama dengan varian Pauh kerana kedua-dua varian dialek tersebut dituturkan di kawasan hulu LST. Secara umumnya penyebaran varian ini dilihat tidak begitu meluas. Hal ini kerana varian tersebut dituturkan oleh penutur informan yang tinggal di KBDR sahaja. Di sekitar kawasan kajian mempunyai bentuk muka bumi yang lebih kurang sama dengan varian Pauh iaitu kampung kajian yang terletak berhampiran dengan hulu sungai, berhutan, bertanah pamah dan pedalaman hulu kampung. Menariknya varian ini kerana kebanyakan informan yang berasal di kampung tersebut menggunakan leksikal [nəkow], [mu $\left.{ }^{\mathrm{w}}\right]$ dan $[\operatorname{dim} \varepsilon]$ yang mana merujuk perkataan /aku//kamu/ dan /mereka/.

\section{f. Varian Kuala Pueh}

Varian Kuala Pueh tersebar di kawasan hulu LST di daerah HT. Varian ini dituturkan tidak begitu meluas kerana kawasan tersebut terletak berhampiran dengan hulu sungai, berbukit, bertanah pamah dan landai. Kebanyakan informan gemar menggunakan leksikal /aku/, /kamu/ dan /mereka/ sebagai realisasi leksikal [akuw ${ }^{\mathrm{w}}$, [mun] dan [dime]. Terdapat sebanyak dua buah kampung sahaja yang terlibat iaitu KKPH dan KDR.

\section{g. Varian Jenagor}

Varian Jenagor tersebar di kawasan hulu LST. Varian ini dituturkan di hulu sungai yang tidak begitu meluas penyebarannya kerana didapati bahawa kawasan tersebut terletak berhampiran dengan hulu sungai, kawasan berbukit bukau, berhutan, bertanah pamah dan juga terletak di pedalaman hulu kampung. Kampung kajian di kawasan berkenaan gemar menggunakan leksikal /aku/, /kamu/ dan /mereka/ sebagai realisasi leksikal [akow ${ }^{\mathrm{w}}$, [mike] dan [dime]. Antara kampung yang terlibat ialah KDSN dan KJNG.

h. Varian Baung

Varian Baung mempunyai pertuturan varian dialek yang tersendiri dan unik. Varian ini dituturkan di daerah HT dan penyebarannya berlaku di kawasan hulu LST. Selain itu varian ini wujud di kampung yang terletak berhampiran dengan pedalaman hulu dan Tasik Kenyir. Varian ini tidak tersebar begitu meluas kerana kawasan kajian tersebut terletak berhampiran dengan kawasan berbukit bukau, berhutan, bertanah pamah dan berhampiran tasik. Kesemua kampung kajian ditinjau di kawasan kajian merealisasikan leksikal /aku/, /kamu/ dan /mereka/ sebagai [akə?], [məy] dan [dimi]. Antara kampung yang terlibat ialah KPK dan KBAU.

Bukti-bukti geolinguistik dan bukan linguistik telah dibincangkan menerusi makalah ini untuk mengukuhkan lagi penemuan kajian iaitu kewujudan lapan varian dialek kawasan sepertimana yang telah dikemukan di atas. Selain itu, dapatan kajian yang diperoleh di sepanjang LST juga membuktikan tiada sebarang penemuan dialek luar atau bahasa Orang Asli di kawasan kajian tersebut. Sebaliknya penutur di sepanjang LST sememangnya merupakan masyarakat kampung yang berasal di negeri Terengganu. 


\section{Kesimpulan}

Kajian ini mempunyai keunikan dan keistimewaan tersendiri yang mana dapat memberi implikasi kepada tiga perkara penting iaitu yang pertama implikasi terhadap bidang kajian geografi dialek khususnya dalam konteks menyumbang kepada penambahan kosa ilmu; kedua, implikasi kajian kepada bidang pendidikan variasi bahasa/dialek Melayu di sekolah, universiti dan kementerian pendidikan; yang terakhir ialah implikasi kajian kepada para ahli linguistik Melayu yang berusaha meneruskan legasi pengkajian dialek di Malaysia dan kelestarian budaya Melayu.

Kajian di sepanjang Lembangan Sungai Terengganu berkaitan variasi aspek leksikal varian Dialek Lembangan Sungai Terengganu telah dilaksanakan berdasarkan cara kerja atau prosedur yang bersistematik. Sebagai sebuah kajian geografi dialek, kaedah pemetaan dalam kajian ini telah mampu mencapai objektif yang disasarkan. Aplikasi GIS yang bertujuan untuk menghasilkan peta digital telah berjaya membuktikan tentang kewujudan varian DLST melalui garisan pemisah linguistik atau sempadan isoglos di antara kawasan-kawasan kajian di sepanjang LST, meskipun penggunaan integrasi pendekatan GIS dalam proses pemetaan masih begitu baru dimanfaatkan dan dipraktikkan di Malaysia.

Tidak dinafikan bahawa pemanfaatan GIS mampu menghasilkan peta dialek yang tepat dan jelas. Gabungan antara dua disiplin ilmu iaitu linguistik dan geografi ternyata berupaya menghasilkan dapatan penyebaran dan kesejajaran varian DLST yang lebih sahih dan menarik. Berdasarkan kajian ini juga ternyata taburan varian dan penyebaran untuk kebanyakan kawasan kajian di sepanjang LST adalah berbeza mengikut pengaruh pertuturan penuturnya dengan keadaan geografi kawasan kajian.

Kajian ini membuktikan bahawa di sepanjang LST mempunyai pelbagai varian-varian dialek yang tersendiri seperti varian Makam Lama, varian Pauh, varian Jenagor dan varian Baong. Hasil kajian turut mendapati bahawa tiada unsur pengaruh dialek luar seperti dialek Kelantan, dialek Pahang dan dialek Perak. Bahkan juga tiada pengaruh bahasa Orang Asli yang wujud di perkampungan Melayu di hulu LST. Varian-varian yang dikenal pasti tersebut mempunyai hubungan linguistik yang rapat dengan DMT.

Penggunaan GIS dalam pengkajian dialek ternyata banyak membantu dan memudahkan pengkajian serta amat wajar diperluaskan lagi dalam kajian Linguistik. A GIS adalah wajar dan mampu dimanfaatkan dalam pelbagai bidang lain seperti dialektologi, pengajian sosial, sains, matematik dan lain-lain. Tidak keterlaluan jika ditegaskan di sini bahawa kajian dialek berteknologi moden wajar diteruskan dan dikembangkan lagi agar dapat menarik minat generasi masa kini dan akan datang untuk mengetahui, memahami serta mempertahankan variasi dialek yang wujud di Malaysia. Ini kerana, dialektologi tanpa sifat multidisiplin dan cakna perkembangan arus pemodenan mampu menatijahkan hilangnya minat generasi muda akan jati diri bahasa ibundanya. Sekiranya situasi ini dibiarkan berterusan maka dikhuatiri budaya dan bahasa Melayu tidak lagi dikenali apatah lagi untuk disanjung tinggi. Apatah lagi apabila kelestarian budaya tidak terbela dan bahasa ibunda tidak lagi bersifat asli seperti dahulu, sekaligus memadamkan pepatah Melayu 'Bahasa Jiwa Bangsa' dari kamus minda penutur Melayu. 


\section{Penghargaan}

Penghargaan kepada Kementerian Pengajian Tinggi atas sumbangan dana penyelidikan FRGS/1/2018/WAB04/UKM/02/2

\section{Rujukan}

Ajid Che Kob. (1997). Word Final Nasal in Malay Dialects. Proceedings of the Seventh International Conference on Austronesian, 35-43.

Ajid Che Kob. (2008). Subklasifikasi Dialek Melayu Patani-Kelantan-Terengganu: Satu Analisis Kualitatif. Jurnal Melayu, 3, 19-30.

Asmah Haji Omar. (1977). Kepelbagaian Fonologi Dialek-dialek Melayu. Kuala Lumpur: Dewan Bahasa dan Pustaka.

Ang Kean Hua. (2015). Sistem Informasi Geografi (GIS): Pengenalan kepada Perspektif Komputer. Geografia-Malaysian Journal of Society and Space, 11(1), 24-31.

Brown, C. C. (1935). Terengganu Malay. Journal of the Malayan Branch of The Royal Asiatic Society, 13, 1-111.

Chambers, J. K. dan Trudgill, P. (1990). Dialektologi. (pntrj). Annuar Ayub. Kuala Lumpur: Dewan Bahasa dan Pustaka.

Collins, J. T. (1983). Dialek Hulu Terengganu. Bangi: Penerbit Universiti Kebangsaan Malaysia.

Habibah Che Rosdi. (2016). Dialektologi Geografi Hulu Perak Utara: Perbandingan Fonologi dan Leksikal. Tesis S. Sa. Pusat Pengajian Siswazah, Universiti Kebangsaan Malaysia.

Haji Muhammad Saleh. (1978). Terengganu dari Bentuk Sejarah Hingga Tahun 1918m. Kuala Lumpur: Anggota Kumpulan Utusan Melayu.

Mohamad Firdaus Azaharudin. (2020). Penelitian Variasi Fonologi dan Leksikal Varian Dialek Lembangan Sungai Terengganu. Tesis S. Sa. Pusat Pengajian Siswazah, Universiti Kebangsaan Malaysia.

Hervey D. F. A. (1881). The Endau and its Tributaries. Journal of the Straits Branch of the Royal Asiatic Society, 7, 93-132.

Ismail Hussein. (1973). Malay Dialects in Peninsular. Nusantara, 3, 69-79.

Lembaga Kemajuan Terengganu Tengah. (2019). Diperoleh daripada www.ketengah.gov.my

Majlis Daerah Hulu Terengganu. (2019). Diperoleh daripada www.mdht.gov.my

Maklumat Asas Sumber Asli dan Alam Sekitar. (2019). Diperoleh daripada www.smanre.my.geoportal.gov.my

McKerron, P. A. B. (1931). A Terengganu Vocabulary. Journal of the Straits Branch of the Royal Asiatic Society, 9, 123-128.

Noor Rohana Mansor, Noraein Mansor \& Normaliza Abd. Rahim. (2013). Dialek Melayu Terengganu: Pendokumentasian dan Pengekalan Warisan Variasi Bahasa Tempatan. Jurnal Melayu, 10, 21-35.

Noraein Mansor, Noor Rohana \& Normaliza Abd. Rahim. (2013). Dialek Melayu Terengganu Pesisir Pantai. Kuala Terengganu: Penerbit Universiti Malaysia Terengganu.

Rohani Mohd. Yusof. (2003). Kuala Kangsar Sebagai Zon Transisi Dialek. Jurnal Bahasa, 3(4), 588-606. 
Shahidi A.H., Mohamad Firdaus Azaharuddin \& Rahim Aman. (2019). Variasi Leksikal Ganti Nama Diri dalam Varian Ulu Berang. Akademika, 89(Isu Khas), 125-137.

Shahidi A.H., Mohamad Firdaus Azaharuddin \& Rahim Aman. (2018). Fonologi dan Leksikal Subdialek Kuala Terengganu. Prosiding Persidangan Antarabangsa Linguistik (PALING) 2018, 173-179.

Shahidi A.H., Rahim Aman, Ab. Samad Kechot \& Sharhaniza Othman. (2016). Penerokaan bentuk keterikatan Melayu melalui ragam bahasa: Perbandingan fonologi Melayu Sadong Sarawak dengan Melayu Semenanjung. Geografia-Malaysian Journal of Society and Space, 12(11), 103-122. 